\title{
Learning Experiences of Young Artists with ASD in a University Enrichment Program
}

\author{
Ching-Chih Kuo ${ }^{1, *}$, Christine Ie-Ting Lin ${ }^{1}$, Bor-Jou Kuo ${ }^{2}$, Ching-Chen Kuang ${ }^{3}$, Ling-Tsai Dai ${ }^{4}$ \\ ${ }^{1}$ Department of Special Education, National Taiwan Normal University, Taiwan \\ ${ }^{2}$ Department of Arts and Design, National Taipei University of Education, Taiwan \\ ${ }^{3}$ Department of Child Care and Education, Yu Da University of Science and Technology, Taiwan \\ ${ }^{4}$ Taipei American School, Taiwan
}

Copyright $(2016$ by authors, all rights reserved. Authors agree that this article remains permanently open access under the terms of the Creative Commons Attribution License 4.0 International License.

\begin{abstract}
Assisting every student with special needs to give scope to their talents and to possess healthy personality and mature social skill that advance their careers at their working places is far from being easy. Within the domains of special education, students are placed in relative disadvantage when they bear cultural differences, and mental or physical disabilities. Their development situation should be given more attention from educators, as the disadvantages they bear might jeopardize the full actualization of their potentials. An enrichment program was started at a university for 5 young artists with ASD during 2012 to 2014, courses include: Creative Design, Art Creation, and Expressive Art Therapy. This paper introduced the artworks of the young artists, their learning attitudes and behavior change after engaged the enrichment program are analyzed by qualitative approach. Data was collected with portfolios, classroom observations and interviews. Among the five artists, three of them were interviewed on the topic of class experiences. Teachers' observations on the learning behaviors were also interviewed. Followings listed the main findings: 1. the learning attitudes became more positive and active wherever in or out schools/universities after joining the enrichment program; 2 . the program opened the space to manifest creativity, 3 . the outstanding performances indicated the artists realized their potentials, and 4. the young artists were more confident and showed less anxiety than before, the interaction among the peers increased through expressive art therapy course.
\end{abstract}

Keywords ASD, Artist, Enrichment Program, University, Learning Experiences

\section{Introduction}

ASD individuals' talents have been found outstanding in many fields, they are talented at some areas but have difficulty with the mechanisms of communication and social adjustment, presenting certain problems of social adaption and integration. The deficits include a lack of empathy and the ability to control emotions, and insensitivity to social cues. Thus individuals with Asperger's syndrome may have difficulties making or keeping friends and have some difficulties in school learning.

In Taiwan, Article 29.2 of the Special Education Act which was amended in 1997 reads:

"Schools at every level shall enhance the identification and consulting service of gifted and talented students with physical or mental disability or bear socio-economic or cultural disadvantages".

The Article provides the legal source to carry out the development and consulting works assisting gifted and talented students with disabilities or bear disadvantages in the society. Some municipalities started to put more attention on the identification and consulting of this group of twice exceptional and culturally different students under the requirement of Special Education Law. A project titled as' Talented Students with and without ASD: Neuropsychological Mechanism and Training of Thinking and Social Skills 'was carried out at NTNU during 2012 to 2014. In the project, the ASD students were reported deficits in social communication and interaction [24]. Notwithstanding their difficulties, many of them demonstrated outstanding talents in painting, music, physics, spatial concept, mechanics and biology. Among them, three are talented in arts. Based on the purpose of developing their talents, we started an enrichment program at National Taiwan Normal University in August 2012. Two female artists joined our program through the referral of National Taiwan University Hospital from 2013. 


\subsection{Talent Performance of Individuals with ASD}

ASD individuals' talents have been found outstanding in fields such as anthropology [31], music [32], calendar [11,21], calculation [21], memorizing [33], poetry [14 ]and art $[6,27]$. Jackson [23] in particular, indicated that the brain structures of ASD individuals are different from typically developing (TD) individuals. With ASD individuals, the areas that are in charge of visual information processing, decision-making and planning are overlapped, this proportionally explains the precision and delicacy of ASD individuals in visual processing related abilities such as painting.

Among all the talents ASD individuals possess, their artistic ability is the most noticed [27], they demonstrate innovations and creativities in their works. Nevertheless, when comparing the creativities of ASD painters, TD art department students, ASD individuals, and individuals with minor learning disorder in their expertise and non-expertise domains, the performances of creativity of TD art department students still exceed the performances of all the other three groups. In spite of having exceptional talents in painting, ASD painters have less flexible thinking and imagination compared with their TD counterparts, they require assistance inspiring their creativities.

Liu et al. [26] found that children with Asperger's Syndrome (AS) performed better in originality and elaboration in the Creative Assessment Packet (CAP) than their TD counterparts; yet they performed less impressive in alternativeness than TD children. Regardless of the different findings in researches, Jackson [23] suggested the employment of music, two-dimensional and three-dimensional arts and multi-media in assisting the development of AS individuals' talents. This could thus establish their confidence, self-esteem and willingness to share with others.

\subsection{Challenges in Cognition and Emotion with ASD Individuals}

Asperger's Syndrome was removed from the DMS-5, students who were identified with AS might be considered as 'supported required' or 'support not required' after the evaluation, and this situation has raised some controversies [25, 18]. Woodbury-Smoth and Volkmar [37] mentioned that despite not having intellectual development disorders, students with AS still face problems with their social adjustments accompanied with physical and mental difficulties, and those are issues for a life time. Frith also pointed out the theory of mind among high-functioning autism (HFA) children [15], they are unable to comprehend the thoughts and emotions of others. Happe [19] proposed weak central coherence theory indicating that AS individuals possess the following difficulties including (a) AS individuals are prone to think locally rather than globally; (b) extreme male brain theory [4,3] in which explains the inadequacy or lack of empathy; (c) mirror neuron system theory [12] indicating the poor imitation skill of people with AS. Despite facing the aforementioned difficulties, Woodbury-Smith and Volkmar believed that their social skills could be improved [37]. For instance, global thinking teaching could improve issues raised from local thinking; moreover, upon learning social norms, forced memorizing could add supplements to the insufficient of role-playing.

Colorado Department of Education [7] emphasized that twice-exceptional students face various challenges in cognition and emotion. Some of the crucial features they bear in cognition open doors for them with their talents. For instance, (a) they have a wide range of interests, and those interests do not necessarily relate with school topics and learning; (b) they have a specific talent or consuming interests area for which they have exceptional memory and knowledge; (c) they focus on their interest on bigger scope rather than its details; (d) they apply their advantages in dealing with certain situations; (e) they demonstrate creativities in accomplishing assigned tasks, which is considered as a technique complementing their disorders. The aforementioned features are some of the positive resources in the development of twice-exceptional individuals. On the other hand, the over-paranoiac interests often contribute difficulties in their adjustments; as a result, proactive consulting services are needed upon the upbringing of twice-exceptional individuals.

\subsection{Talent Development of Twice-Exceptional Students}

The talent development of gifted and talented students is based on assisting them to discover their interests and strengths, advance their learning motives, cultivate their confidence and facilitate them in achieving goals. Van Tassel-Baska, Feng, Swanson, Quek and Chandler [36] pointed that participating in gifted and talented program is beneficiary in boosting the confidence of twice-exceptional students; and will advance their communication and thinking skills. The establishment of a distinctive teaching structure in classes, the provision of an appropriate learning contain that meets the needs of twice-exceptional students, and a curriculum design with distinction hence became the important index when designing curriculum $[7,34,35]$. Colorado Education Department identified the following features could be employed upon providing courses to twice-exceptional students: (a) developing interests and strength of twice-exceptional students; (b) enhancing social skill and emotion development; (c) identifying their difficulties in learning and providing additional assistance; and (d) employing complementary education strategy to assist the development of their abilities. Thus, the curriculum design principles for twice- exceptional students can be summarized as follows: (a) it is recommended to start with the students' strengths and weaknesses in designing curriculum, the insufficient adjustment and a mal-designed curriculum would cause harms to the students; (b) the design of curriculum for twice-exceptional students is in better status when supervised by educators with both disabilities 
and talented education professions. If the curriculum is designed in a different manner, adequate evaluations on students' strength and weakness should be employed to give reference to the adjustment of the curriculum in gifted, special and regular classes to satisfy the learning needs of twice-exceptional students. Therefore, a well-structured and designed curriculum should meet the following criteria in order to deliver the needs of twice-exceptional students to them: (a) additional or advanced materials should be given to in their gifted and talented fields to stimulate their potentials; (b) proportionate learning goals and teaching should be given to in fields that they are averagely developed compared with TD students; (c) complementary education should be placed in subjects in which they perform academically less ideal; (d) flexible and adjustable teaching strategies and material should be applied in accordance with their learning potential and needs in regular classes. Accordingly, Baum [5] proposed Talent Centered Model for twice-exceptional students to tally with students' needs. The elements of the model include: talent development; appropriate learning environment; intellectually challenging curriculum; differentiated instruction and accommodations; targeted remediation; and social and emotional support.

\subsection{Research Questions}

The talent centered model lead the author's action to develop potential of talented students with disability. The enrichment program progressed two years, courses include: Creative Design, Art Creation, and Expressive Art Therapy. Five young artists joined our program, and among of them three are free of expressing their own opinions, they were interviewed on the learning experiences during the two years. This paper introduced the artworks of five artists. The learning attitudes and behavior change after joining the program were analyzed by researchers. Our research questions were as follows:

a. How were learning experiences shared by the participants?

b. How did participants' learning attitude change after attending the enrichment program?

c. Did the program open the space to manifest creativity?

d. Did the enrichment program increase talent development of the participants?

e. Did the program assist the development of interpersonal skills of the participants?

\section{Materials and Methods}

\subsection{Participants}

The participants included young artists, researchers, instructors, parents, and several graduate students working as teaching assistants. Four major instructors were interviewed on the performances of participated students, they are: Prof. Bor-Jou Kuo , the instructor of "Art Creation", who graduated from the institute of Art Studies, New York University, and major in Art Education, Multi-media creation and contemporary art creation. Prof. Ching-Chen Kuang, the instructor of "Creation Design" who graduated from University of Arizona, and major in early childhood education, gifted education and visual arts. Ms. Lin-Tsai Dai, the instructor of "Expressive Art Therapy", who graduated from University of Minnesota, and major in Music Therapy, and Body Movement; Ms. I-Ping Cheng, the instructor of "Expressive Art Therapy", who graduated from Taipei Physical Education College, and major in Dance and Body Movement.

The participants were diagnosed as ASD individuals by the Department of Special Education of NTNU and Department of Psychiatry at National Taiwan University Hospital. The assessment tools include: Wechsler Adult Intelligence Scale (WAIS-III), the Chinese version of the social responsiveness scale (Chinese SRS), and the Chinese version of the adult autism-spectrum quotient (AQ) (Kuo, Liang, Tseng, \& Gau, 2014). Among the participants, due to the restrictions of the lingual abilities, two artists were not able included as interviewees, so only three artists were interviewed. However, most of the parents and teachers were interviewed. The following gives a brief personal profile of five young artists.

\subsubsection{Shane}

Shane (age 18) demonstrates strong interest in the architectures built around 1946 in Taiwan. Through his detail illustrations of Taiwanese street scenes in 1940s to 1950 s, focused on topics such as street scenes, shops, stations, vendors, rickshaws and family ties, great history and social concerns are shown. In his self- introduction, Shane mentioned his 'treasure hunts' in libraries for books on contemporary Taiwanese history with texts and illustrations. These books not only give details on Taiwanese history but also provide fine illustrations; the books trigger Shan's interests and provide examples and epiphanies for Shane's works (AsD0120121224).

\subsubsection{Leno}

Leno (age 20) shows great interests in ancient poetry and revealed impressive talents in it. He is a lover of Chinese literature and started to set foot in Japanese literature. His narrative poems exhibited a combination of diverse literature styles. Leno also began painting over a year ago, he is a self-taught painter with mature painting style that proven his art talents. His poet always shows the easier personality. The self portrait of Leno has no facial features, however vividly expressed flavor of himself.

\subsubsection{Cook Baron}

Cook Baron (age 19) specializes in comics and design, cats are her favorite topic for comics and her works are full of colors and stories. She once mentioned the influence of 
the Cheshire Cat in Alice Wonderland on her works. On her work" Little painter on the canvas', the little bird in the cage is the self-portrait of Cook Baron; The other painting" One person with two stories, One story with two persons" described the inner conflict Cook Baron has been experiencing.

\subsubsection{Leland}

Leland (age 24) is an internationally known artist whose works were exhibited in New York, Prague, Paris, Beijing, Germany, and Netherland etc. He started painting from 4 years old. L.A. Times awarded him as "Remarkable Kids" in 1998 when he was 9 years old. His work 'Leland's Cottage" with more than twenty pieces of his works full of color, love and joy has been exhibited at the Department of Special Education in NTNU as a spot for students to engage in discussions and communications since 2013. Leland has an amazing talent, with sustained concentration while painting, skillful movement in handicraft, perfectionist tendencies. He is talented in many fields, e.g. painting, swimming, equestrianism, and music.

\subsubsection{Wan}

Wan (age 26) loves pottery sculpture, she is very capable in depicting human facial expressions with clay In 2007, her artwork" The Light of Hope" won the first prize of the 2nd Annual International Competition for Artists with Disabilities which was hosted by Phoenix Sister Cities. She enjoys travelling and many of her works derived from her travelling experience, those works include 'Joyful Trains',
'A Joint Ride on Rollercoaster', 'Toy Shopping with Tears', 'English Literature' and 'The Old Oil Well'. Her works are full of childlike innocence, playfulness, and joy. Wan is a girl immersing in her dreams.

\subsection{Research Instruments}

\subsubsection{Enrichment Program}

The weekend enrichment program invited professors in art and music/ dance therapists to host courses in creative design, art creation, and expressive art therapy. Parents and students consulting services were also provided in the program to reduce issues such as anxiety originated from school adjustment and parent-child colliding engagements.

The themes of each course are listed in the following section. 2012 Creative design course included: painting; print making; mask designing; and Chinese painting. 2012 Art creation course include: 1 . inner landscape painting, 2. motorcycle helmet painting, 3 . the surrealism's small theater, 4. woodblock printmaking, 5. "Art Museum" in the classroom, 6. campus painting, 7. flowers still life painting, and 8. mosaic tiles(see table 1). 2013 Art Creation course contained: 1. creation methods and gathering of inspirations; 2 . visual displacement; 3 . the beauty of decorative art; and 4 . collage and assemblage (see table 2). 2013 Expressive Art Therapy encompassed: receiving and expressing; receiving and expressing of music; imitation and interaction; interaction and expression; creation and expression; and dance motion (see table 3).

Table 1. Creative Design Course Outline

\begin{tabular}{|c|c|c|}
\hline Unit & Theme & Introduction \\
\hline 1 & $\begin{array}{l}\text { Application and design } \\
\text { of lines }\end{array}$ & $\begin{array}{l}\text { Appreciating picture books with lines as themes, providing various media for students to take } \\
\text { liberty in creating works with lines. }\end{array}$ \\
\hline 2 & My inner landscape & $\begin{array}{l}\text { Based on the transitions of styles in art history, students created their own pieces expressing } \\
\text { their feelings. }\end{array}$ \\
\hline 3 & Helmet painting & Designing the helmets to experience painting on orbs. \\
\hline 4 & $\begin{array}{l}\text { Human and } \\
\text { environment }\end{array}$ & $\begin{array}{l}\text { Oriented with the environment and visual angel, students reflected their thought on the relations } \\
\text { between people and locations in their works. }\end{array}$ \\
\hline 5 & Surrealist theatre & A theatre with story lines is formed based on the extensive imagination of still life sketches. \\
\hline 6 & Images if literature & Students created their works referencing the illustrations in literatures. \\
\hline 7 & Making of bookplates & Bookplates making with wood printing. \\
\hline 8 & Printing: tress & Training on concentration, perseverance by print making. \\
\hline 9 & Campus sketch & Sketching on campus. \\
\hline 10 & $\begin{array}{l}\text { Another face: mask } \\
\text { making }\end{array}$ & $\begin{array}{l}\text { Exploring emotional expressions with mask making, students learned to transform their feelings } \\
\text { on objects and give lives to their creations. }\end{array}$ \\
\hline 11 & Museum in classroom & Creating through appreciating works in the classroom. \\
\hline 12 & Visible voices & Creating by listening to music or reading books with music as the main theme. \\
\hline 13 & Still life oil painting & Getting to know oil painting styles in art history and conduct indoor oil painting. \\
\hline 14 & A new graphic world & $\begin{array}{l}\text { Based on the works on Dutch artist M. C. Esher, students were introduced to optical illusions in } \\
\text { geometry in order to gain new perspectives in creation. }\end{array}$ \\
\hline 15 & Abstract & $\begin{array}{l}\text { The process of transition from figurative to abstract arts based on Mondrian's Tree series. } \\
\text { Introducing elements as lines, figures, colours and space and the composition of } \\
\text { self-expression. }\end{array}$ \\
\hline 16 & Mosaic & Mosaic art creation. \\
\hline 17 & Presentation & $\begin{array}{l}\text { Presentation held at the Department of Special Education at NTNU, each student presented a } \\
\text { piece of their work to the university as tokens; the pieces were received by NTNU President, } \\
\text { Dr. Kuo-en Chang. }\end{array}$ \\
\hline
\end{tabular}


Table 2. Art Creative Course Outline

\begin{tabular}{|c|c|c|}
\hline Unit & Theme & Introduction \\
\hline 1 & $\begin{array}{l}\text { Getting creation methods } \\
\text { and inspirations }\end{array}$ & $\begin{array}{l}\text { Students were asked to create with inspirations taken from their daily lives and works of } \\
\text { others. }\end{array}$ \\
\hline 2 & Visual Displacement 1 & $\begin{array}{l}\text { Spinning still life. } \\
\text { Getting to know art in an unconventional way with the guidance of the lecture. }\end{array}$ \\
\hline 3 & Visual Displacement 2 & $\begin{array}{l}\text { Value and Chroma of color. } \\
\text { Visiting 'Spring Color Oil Painting' in National Taiwan Arts Education Centre, knowing } \\
\text { the creation, characters and preservation of oil paintings and different styles through the } \\
\text { pieces of sixty six Taiwanese oil painting masters. }\end{array}$ \\
\hline 4 & Visual Displacement 3 & Creating oil painting with the techniques and skills guided by the lecture. \\
\hline 5 & Liberal creation in forms 1 & $\begin{array}{l}\text { A special lecture at the Museum of National Taipei University of Education, getting to } \\
\text { know the planning and concept of the exhibition 'A Contemporary Dialogue with } \\
\text { Michelangelo' }\end{array}$ \\
\hline 6 & Liberal creation in forms 2 & $\begin{array}{l}\text { Visiting ‘A Contemporary Dialogue with Michelangelo’ with Day as the start, } \\
\text { appreciating exhibited pieces included paintings and sculptures. }\end{array}$ \\
\hline 7 & Liberal creation in forms 3 & $\begin{array}{l}\text { Taken the structure, color, techniques of expression and visual angels in others' works as } \\
\text { inspirations and students created their own pieces. }\end{array}$ \\
\hline 8 & Collage\& assemblage 1 & $\begin{array}{l}\text { Visiting the Temple of Shansha with the lecture guiding to experience the beauty of } \\
\text { fragmented ceramic art, wood and stone carving. }\end{array}$ \\
\hline 9 & Collage\& assemblage 2 & $\begin{array}{l}\text { Mixed media creation in Tai-hua pottery with ceramics painting, tungsten alloys and } \\
\text { ceramics color glaze. }\end{array}$ \\
\hline 10 & Collage \& assemblage 3 & $\begin{array}{l}\text { Appreciating oil painting by Miró and Renoir in exhibitions, students' pottery works } \\
\text { accomplished at Tai-hua pottery were shown in class. }\end{array}$ \\
\hline 11 & Presentation & $\begin{array}{l}\text { An exhibition was held during } 25 \text { August and } 1 \text { September } 2013 \text { taking venue of the } \\
\text { Department of Art at National Taipei University of Education, the collections contained } \\
\text { painting and pottery works of the students who participated in the enrichment program. }\end{array}$ \\
\hline
\end{tabular}

Table 3. Expressive Art Therapy Course Outline

\begin{tabular}{|c|c|c|}
\hline & Theme & Introduction \\
\hline 01 & Warm Up & $\begin{array}{l}\text { Introducing the variety of music: listening, receiving and expressing. } \\
\text { Expressing emotions upon appreciating music with painting, the music chosen included } \\
\text { musical (Westside Story), Taiwanese aboriginal Saisiyat tribal music, Cuban Salsa, Indian } \\
\text { music. Students were asked to pay attention to the human voices, drum beats, the sounds of } \\
\text { instruments and tunes in the music. }\end{array}$ \\
\hline 02 & Association of Ocean & $\begin{array}{l}\text { Receiving and expressing music. } \\
\text { Rhythmic movements through waves formed with paper with Hawaiian hula dancing music } \\
\text { and ocean wave sounds as background. Establishing mutual interaction and trust by breaking } \\
\text { personal body space and comfort zone. }\end{array}$ \\
\hline 03 & $\begin{array}{l}\text { Taiwanese Folks Music and } \\
\text { Aboriginal Dances }\end{array}$ & $\begin{array}{l}\text { Various choices of instruments, imitation and interaction, expression. } \\
\text { Self-expressions with percussion instruments and aboriginal music on greetings and } \\
\text { emotions. Students took terms to guess what others were trying to say and painted their own } \\
\text { feelings. }\end{array}$ \\
\hline 04 & $\begin{array}{l}\text { Getting to Know Different } \\
\text { Styles of Dances }\end{array}$ & $\begin{array}{l}\text { Interactions and expressions of music. } \\
\text { Stretched and moved to interact with others using balloons as media, students then played } \\
\text { percussion instruments and painted what they felt in the activities. }\end{array}$ \\
\hline 05 & Exploring Motions & $\begin{array}{l}\text { Music with body motions, improvising and } \\
\text { Started with a Taiwanese folk song, incorporating rhythm beats and dance movements. } \\
\text { Through imitating each other, students learned to improve their social skills and } \\
\text { interpersonal interactions. Students were asked to put their feelings in painting at the end of } \\
\text { the session. }\end{array}$ \\
\hline 06 & Move the Body & $\begin{array}{l}\text { Improvisation of music. } \\
\text { Images of ballet, modern dance and folk dancing were shown to illustrate the space, lines } \\
\text { and strength of dancing human body. Students were encouraged to use ribbons to } \\
\text { demonstrate the beauty, strength and lines of human body. }\end{array}$ \\
\hline 07 & Feedbacks and Discussions & $\begin{array}{l}\text { Sharing the results of interactions based on music and dance via joyful music with peers and } \\
\text { parents. }\end{array}$ \\
\hline
\end{tabular}


Table 5. Coding and meaning

\begin{tabular}{|c|c|c|c|c|c|c|c|}
\hline Coding & 1 & 2 & 3 & $4-5$ & $6-9$ & $10-11$ & $12-13$ \\
\hline meaning & Participants & Identity & Sources & Number & Year & Month & Date \\
\hline content & $\begin{array}{c}\text { Shane: A } \\
\text { Leno: B } \\
\text { Baron: C } \\
\text { Leland: D } \\
\text { Wan: E }\end{array}$ & $\begin{array}{c}\text { Self:s } \\
\text { Mother:m } \\
\text { Teacher: } \\
\text { t }\end{array}$ & $\begin{array}{c}\text { Interview:I } \\
\text { document:D } \\
\text { Artwork:W } \\
\text { Picture: P } \\
\text { Talk:T }\end{array}$ & Shown from 01 & $\begin{array}{c}\text { Shown in } \\
\text { common } \\
\text { era }\end{array}$ & $\begin{array}{c}\text { Months are shown in } \\
\text { numbers }\end{array}$ & $\begin{array}{c}01 \sim \\
31\end{array}$ \\
\hline
\end{tabular}

\subsubsection{Portfolios}

This article provides selected pieces of the three students' works to give reference to their painting styles. The publication of these works is under the permission of the students and their parents. The author also collected relevant documents and materials including the young artist's confession, award winning records, interview transcripts, it is the intension of the author to have in-depth understanding of the qualities and thoughts of these young artists.

\subsubsection{Interview}

The reviews of the NTNU enrichment program are obtained via interviewing participating students and their parents. The interviews were conducted by the research assistants of this program in June, 2014. The assistants were all trained for engaging in interviews as a research method. The interviews were later put into transcript for analytic purposes, and the followings are questions asked. The list of the interviewers and dates of interviews can be found in table 4.

Table 4. Interview questions

\begin{tabular}{|c|l|}
\hline 1 & $\begin{array}{l}\text { How much did you/oo like the enrichment program at NTNU, } \\
\text { and what are the reasons to like it or not? Please give us a few } \\
\text { brief examples. }\end{array}$ \\
\hline 2 & $\begin{array}{l}\text { Did the teachings of teachers in the enrichment program } \\
\text { influence you/oo? Please give some examples. }\end{array}$ \\
\hline 3 & What kind of assistance did the program provide to you/oo? \\
\hline 4 & $\begin{array}{l}\text { Did you find the program assist the development of your/oo } \\
\text { interpersonal skills? }\end{array}$ \\
\hline 5 & $\begin{array}{l}\text { If there are further programs on talent development, will you/ } \\
\text { do you think oo will take part in those programs? }\end{array}$ \\
\hline 6 & $\begin{array}{l}\text { The performance art therapy course provided music, dance, and } \\
\text { art interactive activities, how did you/oo find those classes to } \\
\text { be? And why? }\end{array}$ \\
\hline 7 & $\begin{array}{l}\text { Do you/oo prefer to stay home and create independently or } \\
\text { participate in the enrichment program at universities? Did you } \\
\text { find the program assist your/oo's painting skills in positive } \\
\text { manners? And please tell us in what specific areas did the } \\
\text { program assist you/oo. }\end{array}$ \\
\hline 8 & Please tell us more about what you/oo feel about the program \\
\hline
\end{tabular}

\subsection{Data Coding and Processing}

\subsubsection{Conducting of Transcripts of Interviews}

The transcripts of the interviews were all conducted by the authors independently, in order to take notes of the research process in a more detailed manner and avoid missing relevant detail information, notes on thoughts and observed details during the interview are also written whilst conducting the transcripts. All recording files were listened more than twice, and the relevance of the interviewing manners was exam thoroughly. During the transcript conducting process, the authors also reflects in details on the interactions with the participating students.

\subsubsection{Data Coding}

The coding manner of the interview transcripts and relevant documents is illustrated in Table 5. The first digit represents the participants; the second digit represents the identity of the young artists; digit fourth to fifth show the number; the sixth to ninth digit are the year; the tenth to eleventh digits are the month and the twelfth and thirteenth digits are the dates. For instance, a confession given by Cook Baron on $30^{\text {th }}$ March 2013 is coded as CsD0120130330.

\subsubsection{Data Processing and Analysis}

This research aims on analyzing the students' participations in the enrichment program and their social adaptability changes via quantitative and qualitative means. The quantitative data processed with curve analysis, demonstrating the changes of the three students' social communication and responsiveness before and after participating in the enrichment program. The qualitative analysis included interviews, relevant documents, photos taken during classes and daily conversation records as analytic materials.

\section{Results and Discussion}

Even the two participating students were not included in the interview; all young artists taking parts in the enrichment program had high attendance rate, they rarely missed any class.

\subsection{Positive Learning Experiences during the Enrichment Activities}

The participants showed high interests in the sequence courses at the end of each semester, which could be considered as an indicator for their interests and positive reviews on the enrichment program.

Some class activities were shown by Figure 1 to Figure 6 . In 2012 Creative Design course (see Figure 1), after teacher shared Zhu, Ziqing's article of the back of father, Shane 
drew a picture of the father's back in Zhu's article instantly. In 2012 Art Creation Course, students were very concentrated and each one had his own painting style (see Figure 2). In 2013 Art Creation course (see Figure 3), students were very happy making pottery in Ying-Go which is a town well known by producing pottery. In 2013 Expressive Art course (see Figure 4), after the dancing activity, Shane draw the feeling of dancing which is so vividly (see Figure 5); Cook Baron also draw the feeling of listening and playing Music (see Figure 6). Every teacher was surprised by their talents. Our young artists enjoyed the program by large.

Overall, the participating students and their parents considered the NTNU Enrichment Program as an intriguing and impressive program. The program offered participating students alternative education and creation chances, the recognition and assistance on the students' talents means significantly to the parents. A wide range of art exposure inspiring participating students, which eventually led to the emphasis and assistance on the students' talents development was largely appreciated by the parents.

'The program at NTNU is a very interesting one, and it seems like a once a life time experience to me that I want to seize. As we are special, it is being far from easy for us to make friends, and others don't have such opportunity [...] we also have field trips later on in the program, we went to Shanshia and Yinge, first Shanshia Temtple and Professor Bor-Jou Kuo gave us in-depth guiding tour sharing fascinating things about the temple. Professor Kuo gave very comprehensive guides and instructions, when I see the Shanshia Temple and its carvings and sculptures, I think of Professor Kuo's introduction and the beauties and structures of the temple he told us. We also experienced pottery creation, which was a rare chance.' (AsI0120140630)
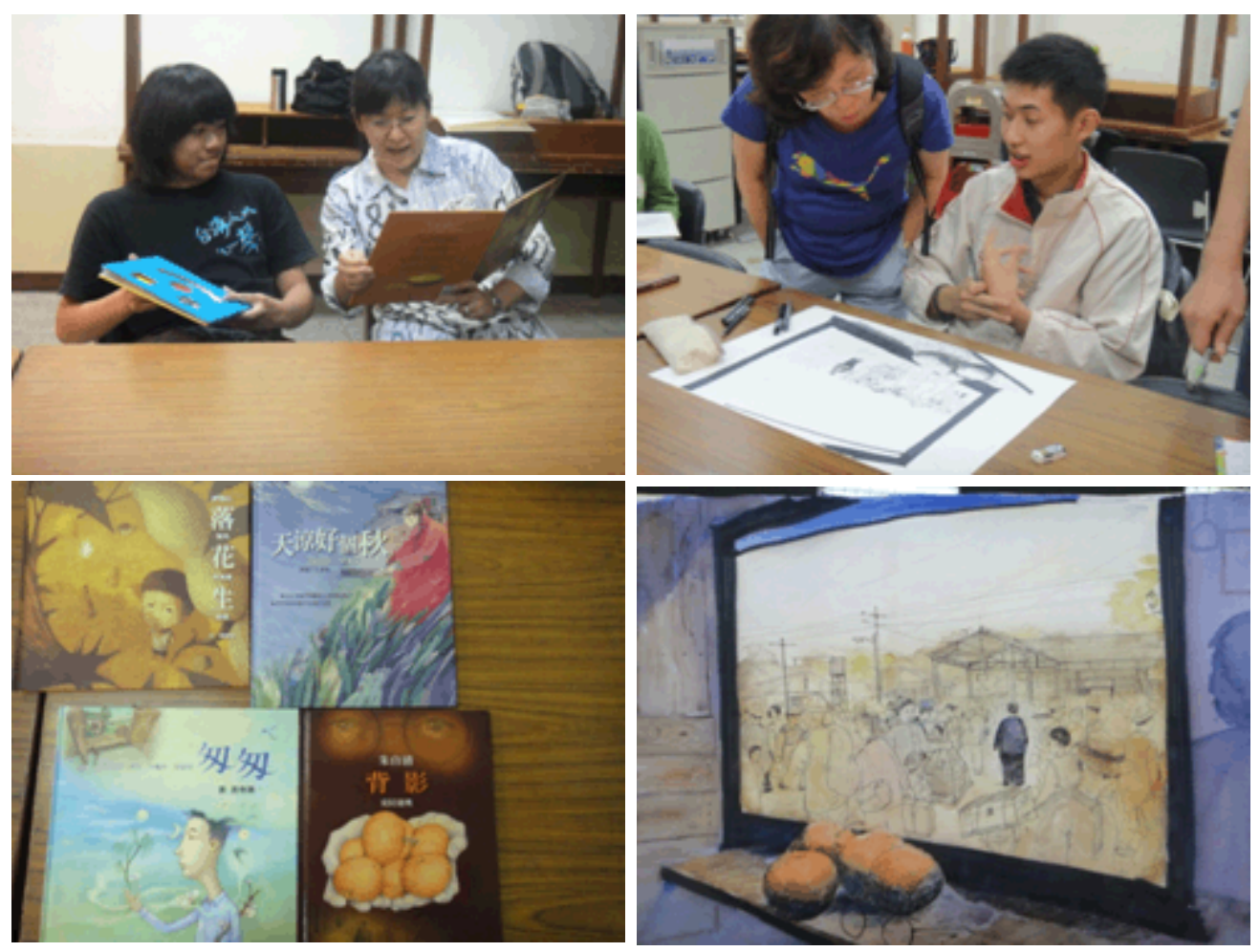

Figure 1. Creative Design Course 

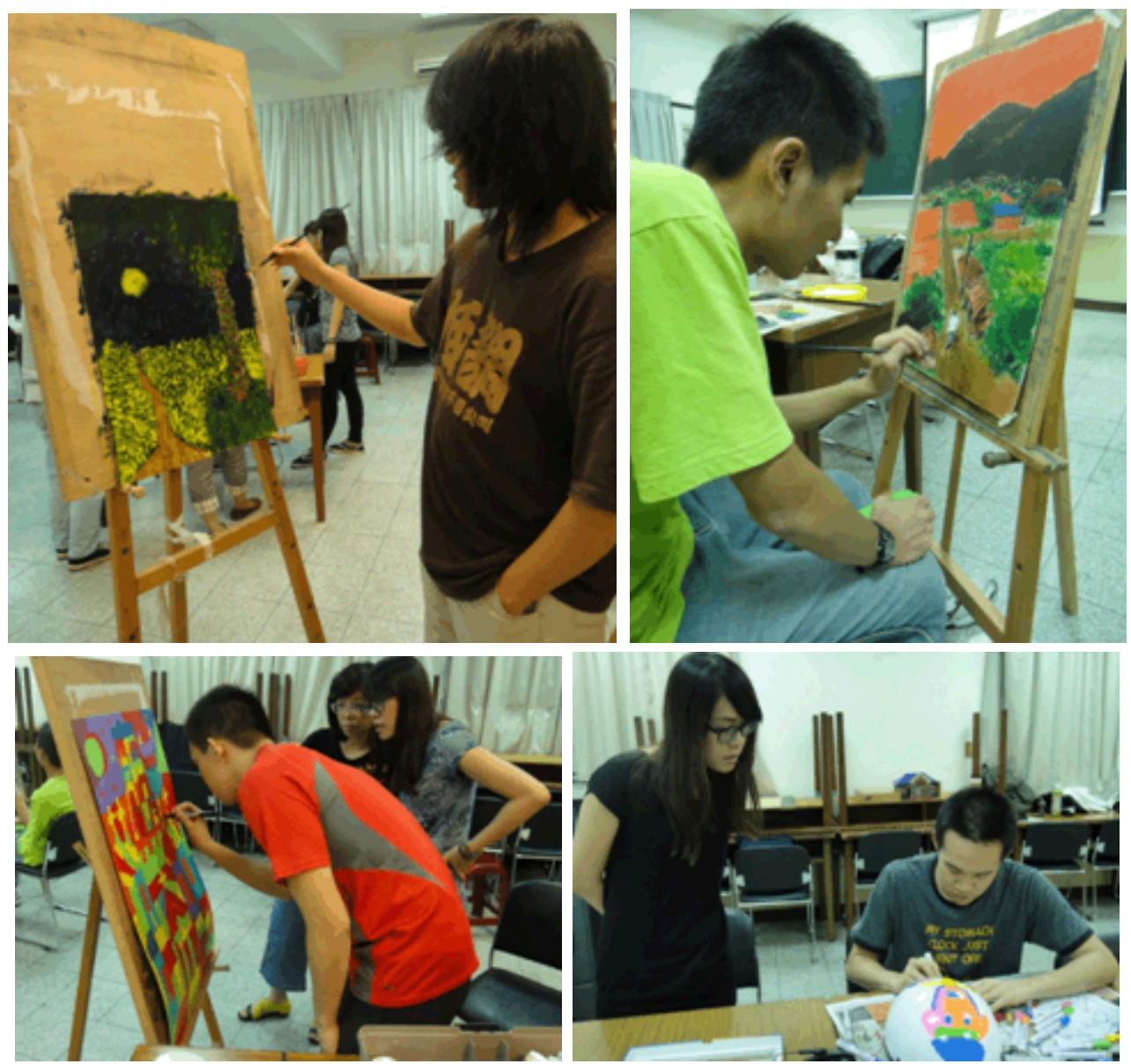

Figure 2. Art Creation Course
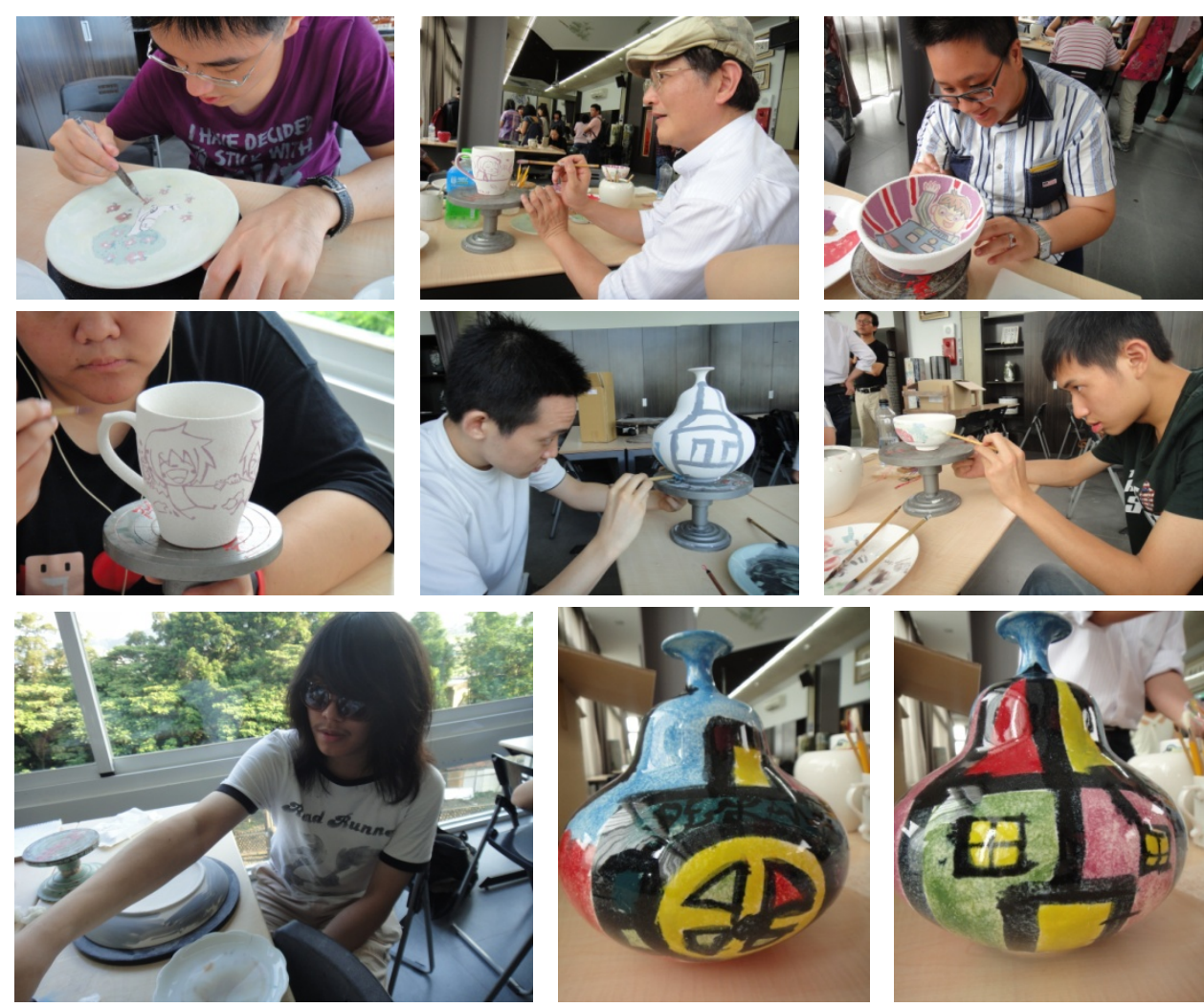

Figure 3. Art Creation Course 

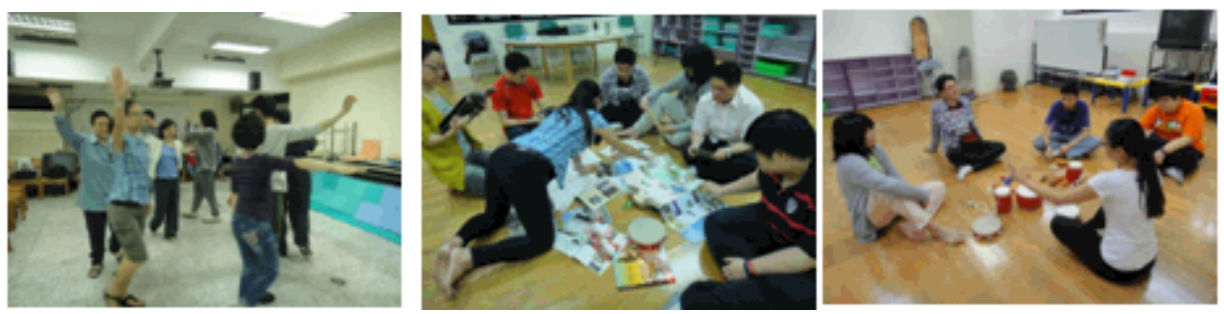

Figure 4. Expressive Art Therapy Course

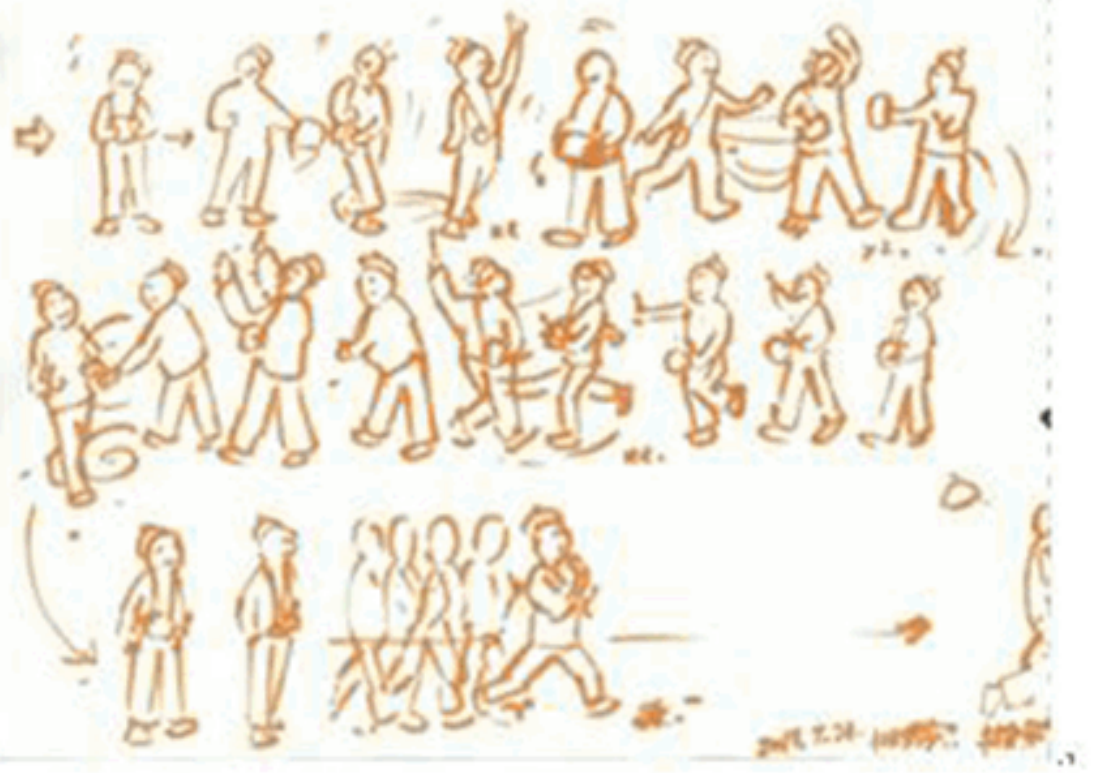

Figure 5. Feelings of Dancing (by Shane)

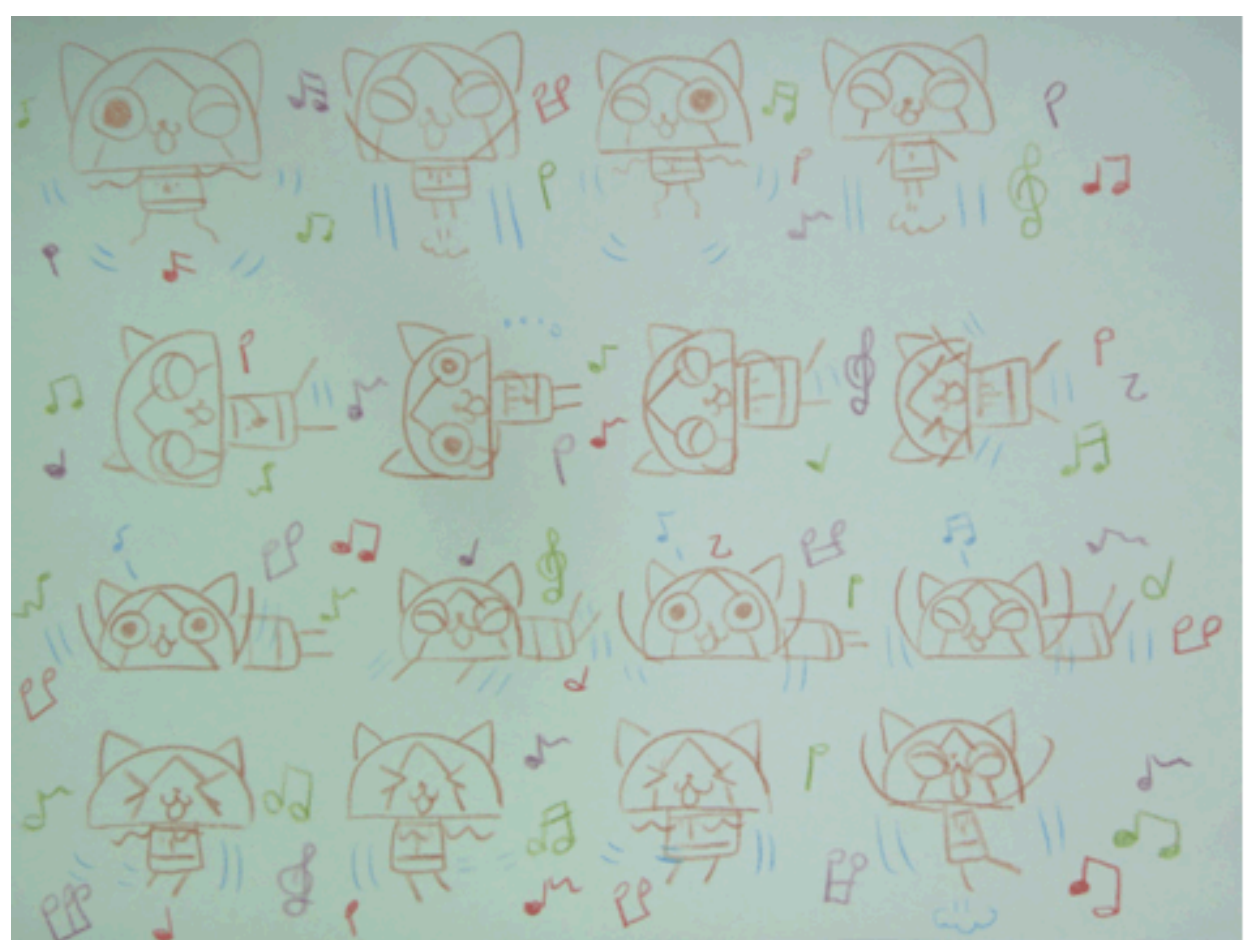

Figure 6. Feeling in Music (by Cook Baron) 


\subsection{Changing Learning Attitude}

In the two-year program, Leno's concentration was an issue for the teachers. Leno had no interest in school subjects in high school and he didn't continue school education after graduating from high school. He woke up at ten in the morning every day, which would not cope with school schedule and regulations in Taiwan.

At the beginning of our program, Leno had difficulty concentrate on what he was not interested in. He always watched other peers, rushed finishing the tasks which were not related with oil painting. He only interested in oil painting. Leno tended to take all the time he had, and he was never in haste. When others put time pressure on him to do more, his reply was always an emphasis on his high concentration and thoughts. However, Leno had a drastic improvement on his attitude in 2013, he was particularly interested in pottery introduced in class and started to set foot in pottery by going to Tai-Hua Pottery in Yinge every week. Leno has already accumulated a large number of pottery works.

Other than attending the enrichment program, Leno's passion for poetry lead him to attend the classes the Department of Chinese at NTNU; and he was able to attend graduate school classes at the department a year after. Leno had always been maladjusted to school life, but he is now an active learner, eager to learn from courses provided by the university. He also devotes himself in writing and creations. The authors witnessed practice of devotion for one's passion on Leno and found it extremely inspiring. Started from 2013, with the encouragements from his mother, Leno overcame his fear and insecurity in learning foreign languages and started learning French, English and Japanese in hopes of improving his lingual ability. He has been taking courses from NTNU, National Taiwan University, and National Taiwan University of Arts for more than three years (from 2013 until now), his diversified choices of education in art, literature, history and languages surely enrich Leno's life.

Cook-Baron particularly adored the program. Cook Baron used to be a student frustrated by university education and she didn't enjoy school. She once wrote

\begin{abstract}
'the time in-between lectures in university is something that many are not acquainted with, for we never experience these "free time" since first grade until attending university. The hours in-between lectures appear to be an imposition rather than a break, since people couldn't head home having lectures after the "break". The break itself doesn't trouble me, I don't like going to school not because I dislike school per se, I am just trouble by going to lectures and commuting. The long break in-between lectures gives me time to draw and time to visit the library, and I enjoy the long in-between lectures break.'(CsD0120130330)
\end{abstract}

Cook-Baron's mother mentioned that Cook-Baron was unhappy at her university at the beginning of the enrichment program. Her communication problems with lectures caused her anxiety, and the anxiety escalated when she misheard the instruction of her assignments or her works were not credited (CmT0120130316). Nonetheless, her performance at NTNU was highly recognized and she was always the first to arrive and sited at the very front of the classroom with great enthusiasm to learn. Her works were presented at the Department of Special Education at NTNU, she mentioned

\begin{abstract}
'When I started the enrichment program at NTNU, I was not very fund of the program at the beginning. After getting used to the program, I found that I am able to conduct my own piece from what I've learned from the professors, this makes me very happy and I learned much.'(CsD0220130912)
\end{abstract}

Shane always concentrated on all the activities. His serious and good learning attitude leads to his improving performance in academics in his high school. His piece "Van Gogh Can Take A Rest Now" in art class was given 96 out of 100 by his art teacher in high school. His painting picturing the famous night market, "The Circle" embedded in all common memories of people from Taipei is astonishing and the first author would also like to give him ten out of ten for this piece.

\subsection{Open the Space to Manifest Creativity}

\subsubsection{A Program which Diversities in Teaching and Teaching Materials}

The NTNU Talent enrichment program emphasizes the diverse topic design in the courses to assist students developing their potential and exploring more possibilities. Not abiding the conventional art education given in schools is also a stimulation to the participating students on manifest their creativity.

Prof. Kuo B talked about the experiences working with the participants:
"I figured out that these young people really mind and specialize in their own field of studies. For instance, Shane conducted effective elaboration on the realism details. Everyone specializes in his own field and when it is fixed, even if we try to revise it, the likelihood is still not very high. But there is something we could put in mind, "to beat around the bush"; we could notify them with the fact that is there anyone else who's got the same style of drawing. I suggest that art learning should be with higher variety and diversity. The reason why I often show them with collections of paints is that I want them to reinforce on the strong foundation that they already owned, that is to say, to broaden other possibilities as well as keep what they've already owned."
"In between interacting with them, I think it's somehow a growth and learning for I myself. This is the first time I am faced with these unique students, and I figured out that correspondingly, they've got 
unique performance in painting performance. This is what ordinary people could not perceive. Taken Shane's meticulous illustration on street views and perspective. Taken Leno's abstract, blazing performance. Art majors of his age cannot reach such level. My sense of achievement resulted from seeing their confidence and their adamant in art. I think this quite good."

\subsubsection{Out of the Classroom and Out of Box}

The Enrichment Program was designed to always be out of the box and sometimes out of the classroom. Field trips are some of the highlights in the Enrichment Program, and through visiting exhibitions with guiding tours given by professionals and visiting other workshops and studios, students are given chances to try out different and new things. These visits also open new doors for the students as Leno started to make pottery at Taihua Pottery after visiting the workshop, and Leno found his interest in pottery creating there. The Enrichment Program aims on providing wide exposure on various forms and styles of art to the students, as much of the time the new thing might eventually become their new possibility and favorite thing.

Followings are some point of views the young artists experienced in this enrich program.

'I found it extremely interesting with the group presentation, and we were told that each of the thinking hats has its own mindset and we should not repeat what has already been told by others, we need to be very creative. That was an interesting class and I remember everything so vividly. There was also a class that we put our creativities into daily technologies, and we made robots. I am not the handiest person but the teacher guided us so well that I enjoyed making my own robot with some technological elements.' (AsI0120140630)

'It is fun, the first session encouraged us to use different materials in our works and the second session gave us great liberty in creation. I like the field trips too because of what I've seen and experienced in the trips. '(BsI0120140619)

'I used to restrict myself to create with one sort of material, and we were encouraged to use multiple ones in one piece in the Enrichment Program, this helps me in applying different styles and materials in my works. '(CsI0120140620)

'Creativity is like to jump out of my own box, the box that I am so used to and comfortable with. But now I often think of what I was told in the program, to jump out of the box, and I just do that to help me creating. It was quite tiring at the beginning.....'(CsI0120140620)

'I remember once there were different kinds of music played in the class, and we created according to what we feel about the music, they said that the music played helps us to work on art. My emotion transitions reflect on my works; in particular on abstract paintings. '(CsI0120140620)

'When I have more materials to opt for, I feel that my works are different. Even though with the same topic, my works are not the same anymore' (CsI0120140620)

'I found different creating materials, and I got my chance to Taihua Pottery every Wednesday now. 'The field trips and robot making have more influence on me, I discover new materials upon doing pottery in Yinge. '(BsI0120140619)

'I had my first try with oil painting in the program, it's new and fun to me, or I should say it's amazing to me. I had never tried oil painting before, and I guess there's always first time for everything, and the first time is always sort of experimental. I think I will have more chance to work on oil paintings, and because I was told to create with all sorts of materials, I had my work 'The Circle 'with such spirit.' (AsI0120140630)

As the program is designed to assist the talent development of ASD students, encouraging them to experience new forms and styles of art and be out of their comfort zones are what the teaching team worked towards. Take Shane for example, Shane started to paint with color in the Enrichment Program, and those color put more energy and human touch in Shane's paintings, he also has done his very first oil painting in the program. And for Cook Baron who studies in an art-related department at university, she was constantly encouraged to create outside her comfort zone without the pressure she felt at school. It is definitely not an easy task for Cook Baron, yet she tried very hard in doing so. As school art education is confined with specific curricular, it is not so likely for students to have such a wide variety of exposure. Nonetheless, their horizon can be broaden when new things are introduced to them and offered them opportunities to try.

'I am very aware of the vicious circle of staying in my own comfort zone, and I don't like that to be honest. But I just craw back to my comfort zone in creating with frustration each time I tried to be out of there. The program gave us chances to work on different and new materials and I can move out of my comfort zone step by step, not like my own try in haste and ended up back in my comfort zone with frustrations.' (CsI0120140620)

'He (Shane) really enjoys the program and so do we, as parents. It's truly a win-win situation when a research institution gives attention to our children, observe and train their talents while conducting researches. To be more concrete, the program is way more flexible than conventional school education, there is no test given to students and the program focuses on the children's strength, gives great space and freedom to them. The program recognizes their abilities and talents, and assists them on their creation extensively along with their peers and the uniqueness 
within each of them. I feel that we are trusted and recognized by NTNU and I am flattered!' (AmI0120140630)

Prof. Kuang taught Creation Design course. When asked about how did the course develop the talents? She said:

\begin{abstract}
"Although the participants draw and paint well, the theme and the materials of the course promoted the participants' creative and imaginative thinking. Shane can copy the images that he sees, or he can remember them from the past. On mask design, Shane drew a forest. The trees had blue trunks that looked like tears. After viewing the illustrations in the picture books, which were related to those of the Dutch artist M. C. Esher, Shane drew the town on the hill. The people in his drawing sit near windows and interact with others from different angles".

"Leno loves to paint in an abstract style; the theme of each unit invited him to think and try something new". "Continuing the supportive educational system is essential if the participants are to expand their lives. The continued support for their families is essential as it provides family members with appropriate methods for guiding the participants".(t220140625)
\end{abstract}

\subsection{Outstanding Performance}

In 2014, participants of the enrichment program were awarded with different honors, and they demonstrated their exceptional gifts and talents. One of our students, Leland which was not able to be interviewed because the limits of free expression by words, was awarded the Ten Outstanding Young Persons of the Year; he was elected among numerous eligible nominees. The first author mentioned in her endorsement to Leland for the award that Leland stands as the role module of all mental or physical disordered individuals and all young people. It would be the greatest testimony of successful special education if all disordered individuals could be as persistent and brave as Leland in pursuing the actualization of their gifts and talents. It would simultaneously be an enormous gift to the society and country.

Shane is a serious student who accepts all the courses with delights, and a gentle person in character. He continuously works on his pieces and expands his scope into prints, water color, oil painting, pottery, and Chinese painting after participating in the NTNU enrichment program, adding more diversity in his works. Shane also attended Art Concourses, and his artwork 'Times of Mountain Morning' was awarded first place in Chinese painting in the High School Student Art Concourse in both Taipei City and Taiwan (see Figure 7-1).

Leno was awarded the 2012 Outstanding Physical and Mental Disabled Art Creations Award, he also won the second place in Shiuan-guan Award of Talents with his poems. Leno's painting styles change constantly, it could be seen from his figure sketches in 2009 and 2014. His works become more delicate and reflects personalities in news events (see Figure 8-1,8-2).

Leno's mother said:

\section{'Leno gained so much in the program, and because he was in the program so he got his studio now. Not having to know Professor Bor-Jou Kou, he wouldn't have his current studio. Leno was about to start his large size paintings and there was no space at NTNU for that, Professor Ching-Chih Kuo's office was piled up with Leno's paintings that she couldn't enter her own office.' (BmI0120140619)}

Cook-Baron won the third place in the 2013 Autism Painters Awards held by Autism Society Taiwan. Her works on cartoon cat figures are very popular in an exhibition held in Beijing and interested local manufactures, some of her works are printed on goods in cultural and innovative industry and being massively produced. This opened a career opportunity for Cook Baron and might be a career that she can support herself in the future. In the International Symposium on Autism Spectrum Disorders held by the author on the 2014 World Autism Awareness Day, She designed our poster and program book and revealed childlike playfulness. However, we can detect her inner conflict through her artwork titled as "One person with two stories, one story with two persons" (Figure 9-1) and the need of having friends through the painting "The Journey Begins" (Figure 9-2). 


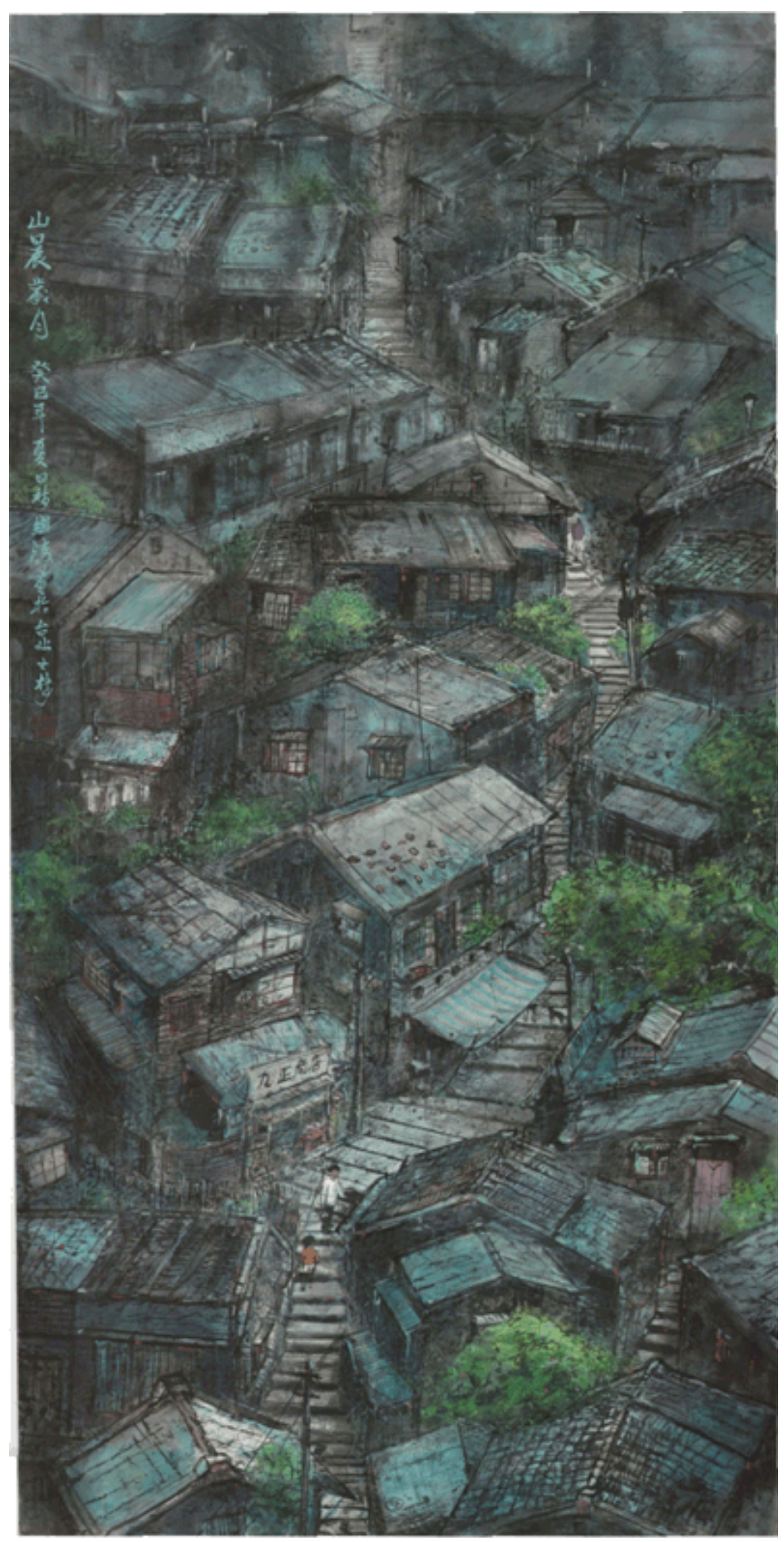

7-1 Times of Mountain Morning 


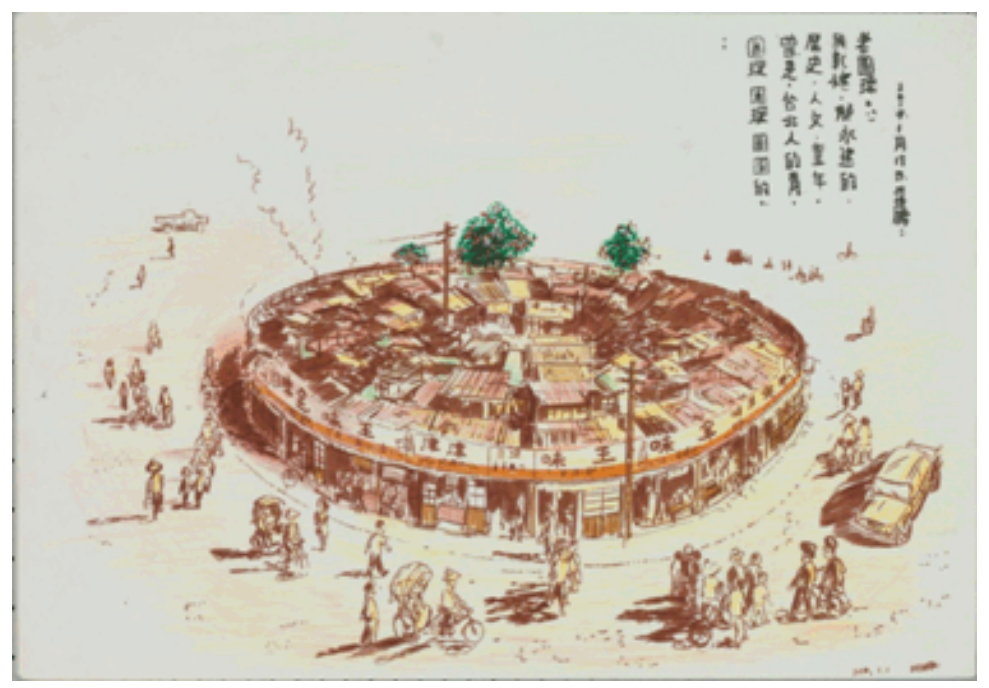

7-2 The Circle in Memory, Taipei

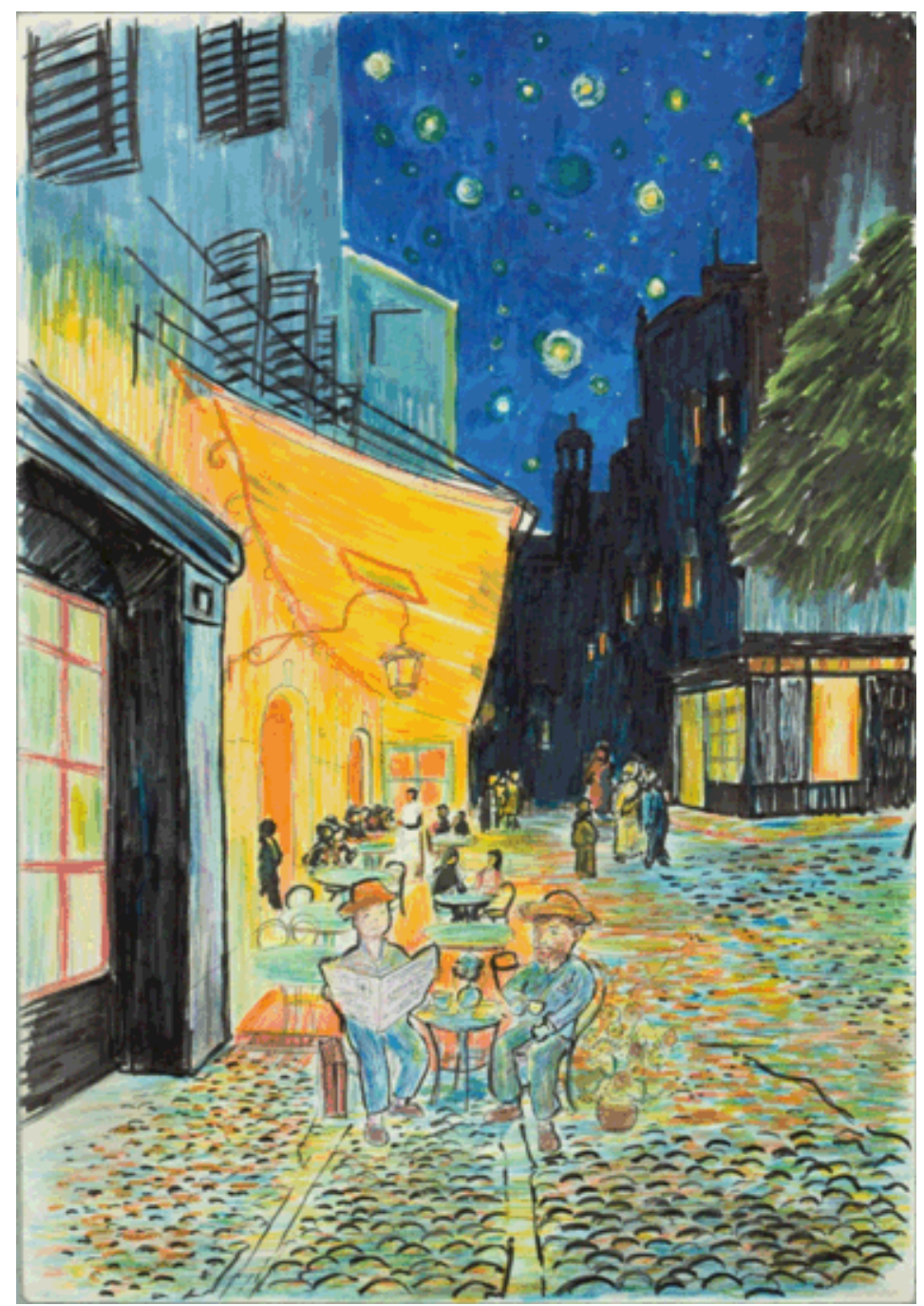

7-3 Van Gogh Can Take A Rest Now!

Figure 7. Artworks by Shane 2014 


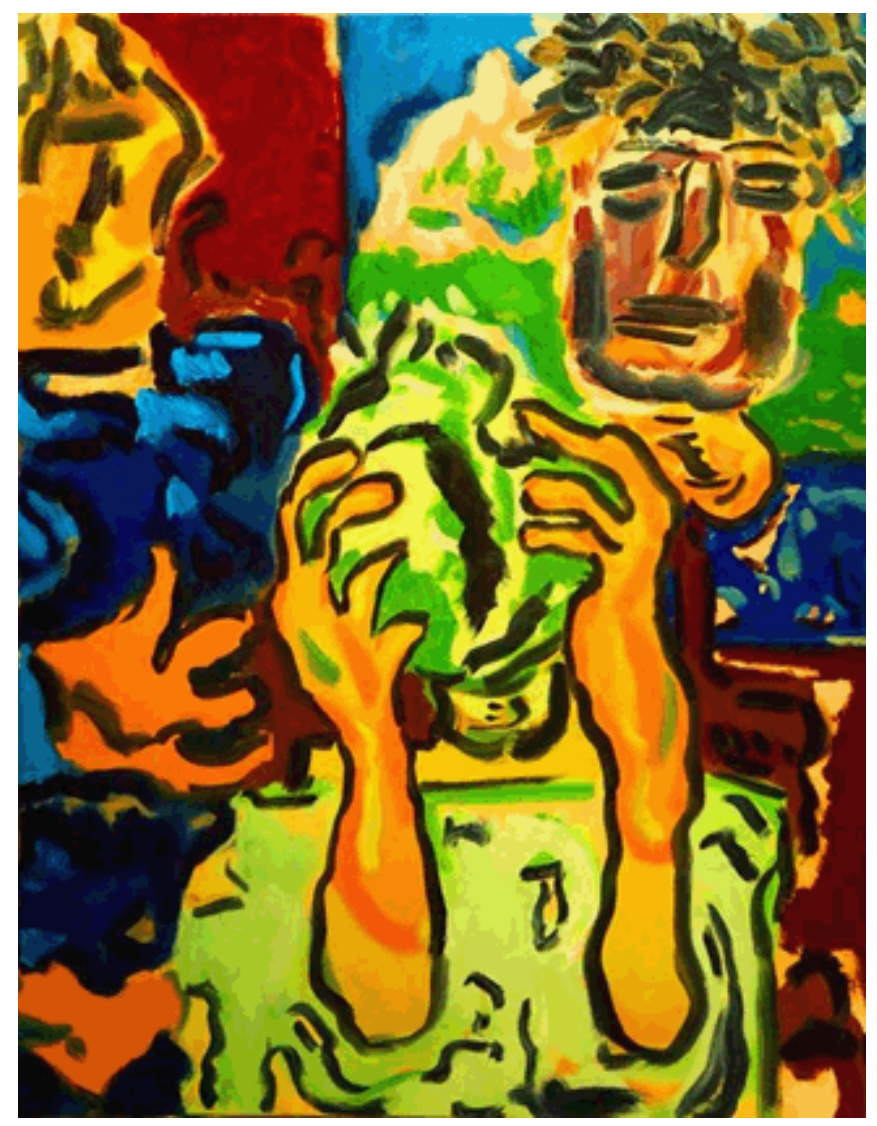

8-1 Bristle with Anger of Genius

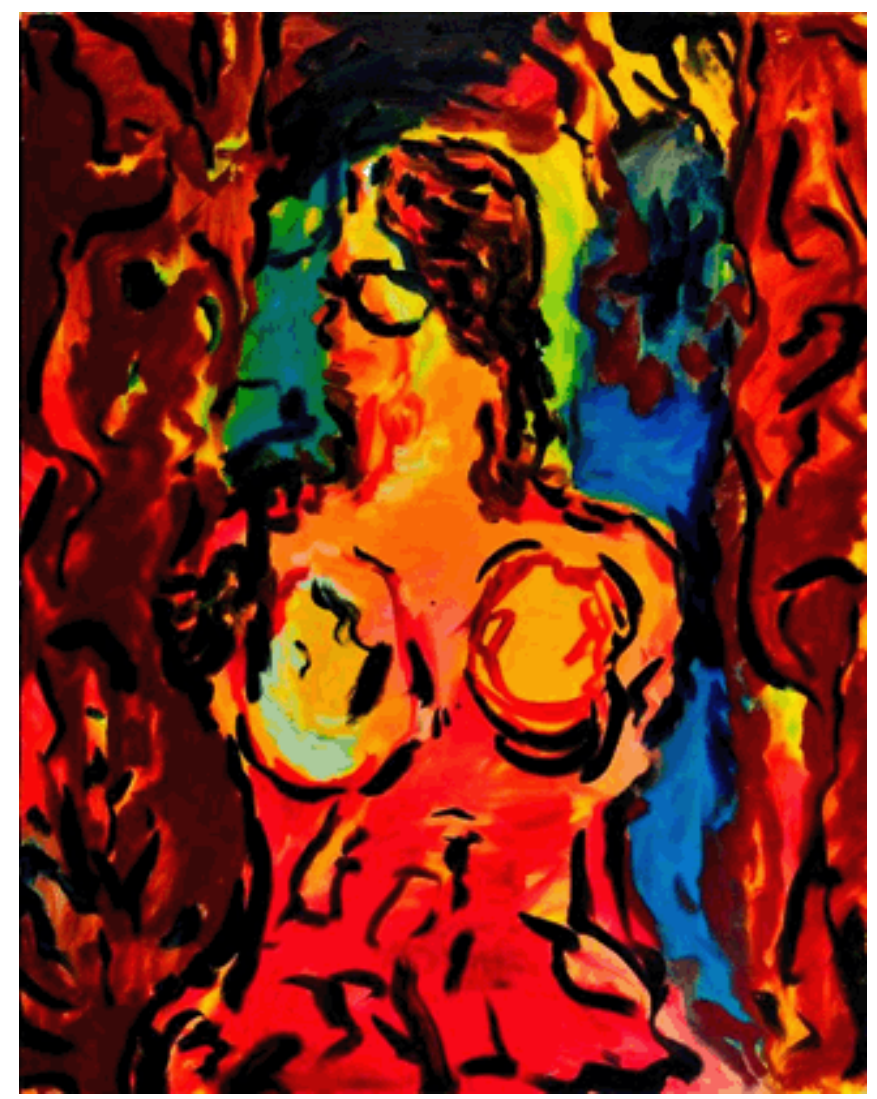

8-2 A Woman Visitor Exhibition

Figure 8. Characters Sketches by Leno, 2014 


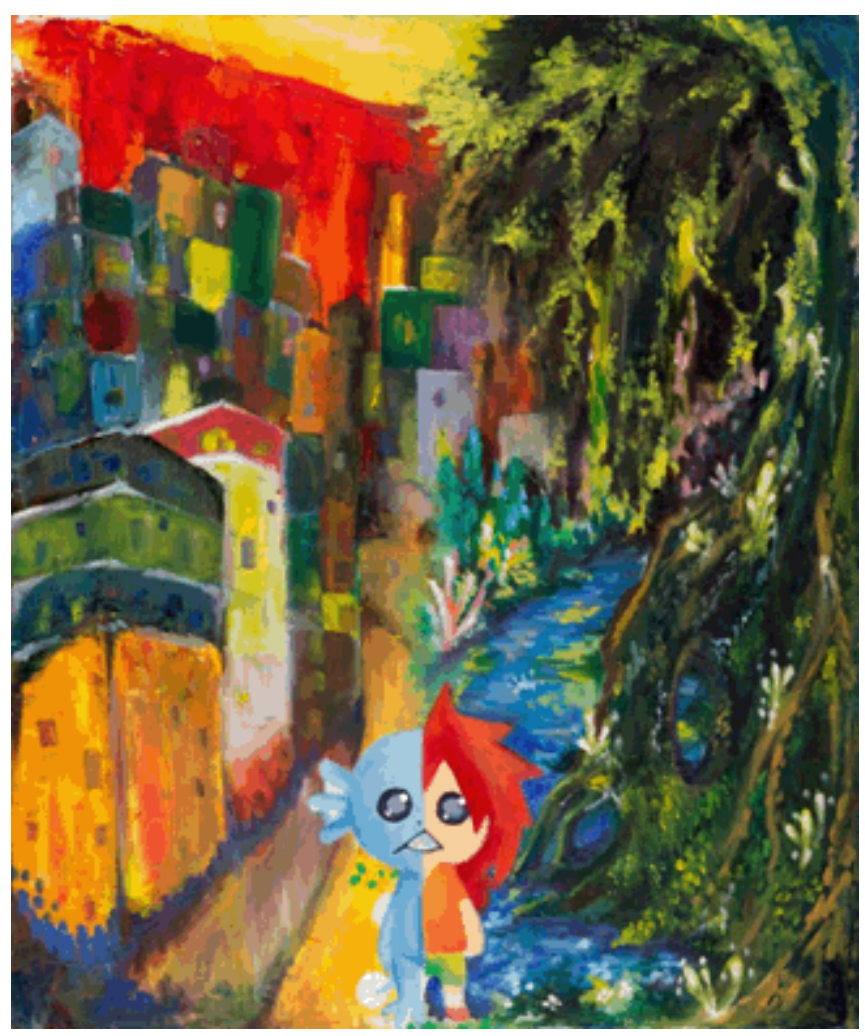

9-1 One person with two stories, one story with two persons

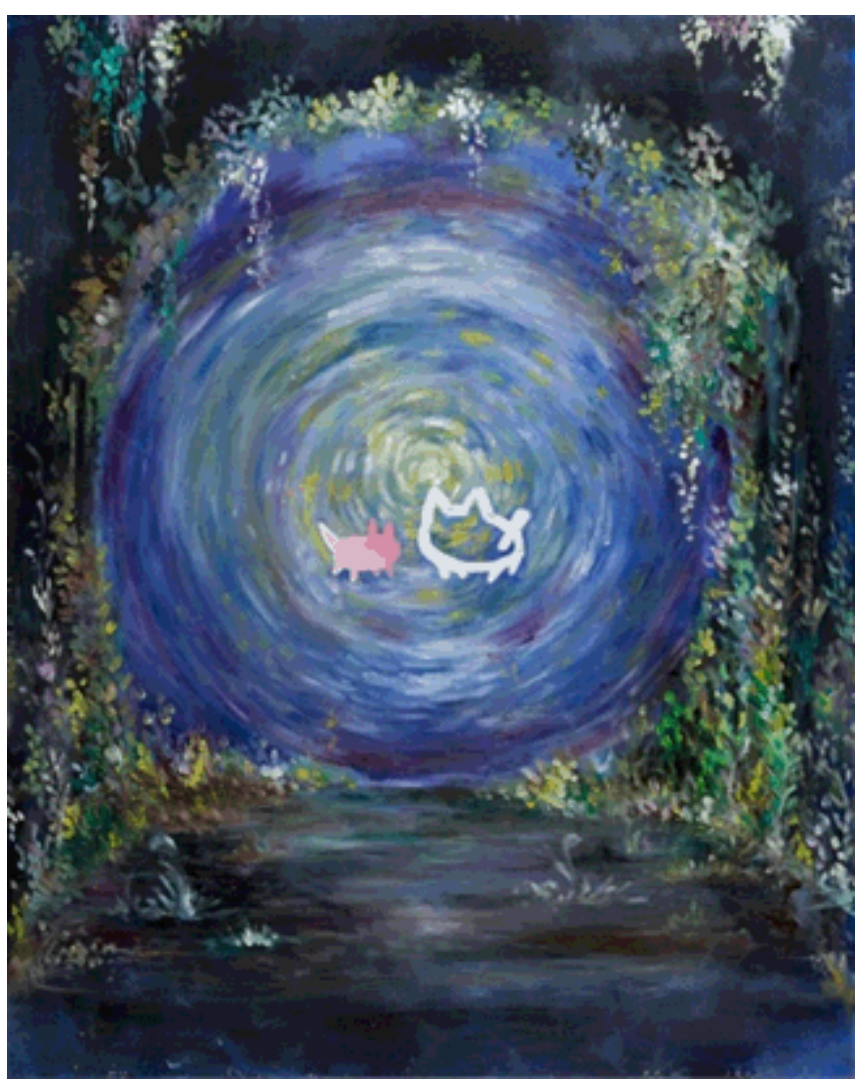

9-2 The Journey Begins

Figure 9. Inner Conflict and Need of Friend by Cook Baron 


\subsection{More Interpersonal Interaction}

While being interviewed on the topic whether participants change in social behavior, Kuang said:

"During the course, the students' interactions improved. If someone was not in the class when I began the class, one of them always reminded me who was not there yet. At the end of each class, the participants were encouraged to talk about what they were creating so they would be aware of the feelings gained from sharing".

"In the second semester, I visited the Expressive Art Therapy Course and had a chance to chat with Shane. He was very excited to tell me about his new classmates", "The small group became a family".

"The participants gradually came to know each other. Shane often gave Leno positive feedback that allowed him to get into the theme".

Prof. Kuang said more, "One thing is quite important, we can see they show empathy. Leno loves to have classical music playing while he paints. When he knew that someone found the music distracting, he turned it off immediately". (t220140625)

Leno' mother described the behavior change of her son:

"I think he has more physical or facial expression now, he started to wink to me, of course, it never happened before. .... it is because the impact of the rhythm of his class, although he is not admitted". (BmI0120140619)

"Leno doesn't like things to change, he likes to go to the same restaurant, to eat the same food, but because the program, his interaction with others improved significantly. For example, when we exhibited paintings in 2014 World Conference on Gifted Children, Cook Baron asked Leno to change the placement of his artworks. Leno gave positive response and moved his artworks to the corner instead of putting them in the middle part of exhibit room, because his artworks are really not suitable to be put in the middle location". "I feel he has better interaction with others, and he shows more confidant and cheerful than he was at senior high school!" (BmI0120140619)

The fourth author of this article was one of teachers of "Expressive Art Therapy". She designed music therapy activities for applying musical elements to design different music/body exercises as foundations and to be used as intermediaries, to understand how students accept and react to various external stimulations through observing student participation. Ms. Dai said:

"Although during the design of the course, "improving interpersonal relationships" was inserted into the short term expectations, due to each student exhibiting unique personality traits, I maintained a positive and conservative attitude before the conclusion and evaluation of the seven activity sessions. Comparing notes after each session and after the completion of the seven sessions, overall, among 6 students, 4 attended regularly. Since the first session, surprisingly, students showed high levels of interest and participation toward the new music/dance lessons. Those students in attendance all gave (or requested, asked, questioned) the teaching instructor complete support and response (some in their individual unique ways). Since then in the following 6 sessions until the end, it was observed that student cooperation increased with the teacher, among other students, when asked to participate whether asked, or actively seeking (verbal/non-verbal)."

Followings are her observation on Leland, who was not interviewed for the reason of verbal communication.

"Among these students, I would most like to share the progress of the oldest Student, at age 27 with the weakest verbal communication skills. At the first session, there were no active interactions with the teacher or with the other students. Upon hearing his/her name called, a head would be raised with eye contact. The student was able to say his/her own name. Unless the question requires an answer in monosyllables such as yes, no, like, dislike, OK, not $O K$, responses were through eyes or smiles to replace verbal communication".

"In terms of body gestures, he exhibited high abilities of imitation and the ability to follow instructions to arrive at the expected results. Starting with the second and third session, he started to show more facial expressions and increased the number of words in replies and frequency, and would raise his/her head to look at the teacher and smile. He would also pay close attention to other students in the middle of their exercises and would smile".

"From the third session to the last, he improved significantly in response to the environment (parents, assistants, other students, displays in the room, instruments, etc.), in interpersonal interactions (teacher/students), in receiving and expressing, as well as verbal/nonverbal communication. He was able to respond in more complete sentences to questions or prompts and took more initiatives to articulate his opinion. When explaining and sharing his works and when offering feedback to other students, these changes were clearly visible. Furthermore, he showed unbelievable performance in dance/body movements with a high sensitivity to rhythm and tone fluctuations. In imitation and improvisation, minor and major movements, touch/recognition/hand eye coordination all showed outstanding abilities."

"He will take the initiative to change movement sequences or create sounds by hitting and pounding to integrate into group exercises and will also observe those around to see if his/her own expectations were met."

(t320140708) 


\section{Conclusion and Suggestion}

In conclusion, the most extraordinary feature of the NTNU Enrichment Program from those artists' view was that the program encourages them to use creativities and imaginations to create their works out of the box. All of their fruitful and impressive achievements are joys to their families; and to their parents in particular. These young fellows with ASD underwent various hardships throughout their education and learning; yet they have proven themselves to be exceptionally gifted and talented with their hard works. These honors are not only the achievements of these young peoples but also the tremendous social capital of our society. Their experiences will also be inspirations for students with special learning needs. In line with the positive experiences for offering enrichment program for young artists with ASD, the authors will continue to assist the ASD students to develop their talents, social skills and career opportunities in hopes of facilitating the development of other ASD individuals via the support system.

As Kuang said: "This project was based upon the ancient China philosopher, Confucius (circa 551-479 BC), who said, 'I instruct all and reject none.' Students who have Asperger syndrome should have an equal opportunity to obtain an education. Mentor models may provide an appropriate way to match the autistic students' special needs and their strengths. Consideration should be given to developing family activities that facilitate the development of the students, and mentors should be encouraged to become more deeply engaged with the curriculum so they can fully support the students".

By using Baum's Talent Centered Model [5], we offered an opportunity for the young artists with ASD attended an enrichment program held at one of top universities in Taiwan (NTNU). The young artists were profit from an open environment which increased their positive learning attitude, creativity, art performances and interpersonal abilities. These indicated that the twice-exceptional individuals can be benefited from a positive support environment in boosting their confidence, advance their communication and increase thinking skills [36]. Based on the aforementioned successful experience of the enrichment program implemented by NTNU, each local bureau of education in Taiwan have started the enrichment programs for discovering and nurturing twice-exceptional students with Talent Centered Model. We hope that there will be more 2E students benefit from such kind of educational services and thus are able to develop their high potentials.

\section{REFERENCES}

[1] American Psychiatric Association (2013). Diagnostic and Statistical Manual of Mental Disorders, DSM-5., Arlington, VA: American Psychiatric Publishing.

[2] Autism Speaks (2013, December 20). Severity levels for autism spectrum disorder. Retrieved from http://www.autismspeaks.org/what-autism/.

[3] Baron-Cohen, S. (2002). The extreme male brain theory of autism. TRENDS in Cognitive Sciences, 6(6), 248-254.

[4] Baron-Cohen, S., \& Swettenham, J. (1997).Theory of mind in autism: Its relationship to executive function and central coherence. In D. J. Cohen \& A. M. Donnellan (Eds.), Handbook of autism and pervasive developmental disorders (pp.880-893). New York: John Wiley \& Sons.

[5] Baum, S. (2009). Talent Centered Model for Twice Exceptional Students. In Renzulli et al. (Eds.). Systems \& models for developing programs for the gifted \& talented, 2nd ed., 24. CT: Creating Learning Press.

[6] Cardinal, R. (2009). Outsider Art and the autistic creator. Phil. Trans. R. Soc. B 364, 1459-1466. DOI: $10.1098 /$ rstb.2008.0325

[7] Colorado (2009). Twice-exceptional students gifted students with disabilities: An introductory resource book. CO: Colorado Department of Education.

[8] Constantino, J. N. (2005). Social Responsiveness Scale (SRS). Los Angeles, CA: Western Psychological Services.

[9] Constantino, J. N., Davis, S. A., Todd, R. D., Schindler, M. K., Gross, M. M., Brophy, S. L., Reich, W. (2003). Validation of a brief quantitative measure of autistic traits: comparison of the social responsiveness scale with the autism diagnostic interview-revised. Journal of Autism and Developmental Disorders, 33(4), 427-433.

[10] Constantino, J. N., Hudziak, J. J., \& Todd, R. D. (2003). Deficits in reciprocal social behavior in male twins: evidence for a genetically independent domain of psychopathology. Journal of the American Academy of Child \& Adolescent Psychiatry, 42(4), 458-467.

[11] Cowan, R. \& Frith, C. (2009). Do calendrical savants use calculation to answer date questions? A functional magnetic resonance imaging study. Philosophical Transactions of the Royal Society, B, 364, 1417-1424. DOI: 10.1098/rstb.2008.0323.

[12] Dapretto, M., Davies, M. S., Pfeifer, J. H., Scott, A. A., Sigman, M., Bokheimer, S. Y., \& Iacoboni, M. (2006). Understanding emotions in others: Mirror neuron dysfunction in children with autism spectrum disorders. Nature Neuroscience, 9(1), 28-30.

[13] Darden-Brunson, F., Green, A., Goldstein, H. (2008). Video-based instruction for children with autism. In J. Luiselli, D. Russo, W. Christian, \& S. Wilczynski (Eds.), Effective practices for children with autism: Educational and behavioral support interventions that work (pp. 241-268). Oxford: University Press.

[14] Dowker, A., Hermelin, B., \& Pring, L. (1996). A savant poet. Psychological Medicine, 26, 913-924.

[15] Frith, U. (1989). Autism: explaining the enigma. Oxford, UK: Blackwell. Grandin, T. 2009. How does visual thinking work in the mind of a person with autism? A personal account. Philosophical Transactions of the Royal Society, B, 364, 1437-1442. DOI:10.1098/rstb.2008.0297

[16] Gau, S. S.-F., Lee, C.-M., Lai, M.-C., Chiu, Y.-N., Huang, Y.-F., Kao, J.-D., \& Wu, Y.-Y. (2011). Psychometric properties of the Chinese version of the Social 
Communication Questionnaire. Research in Autism Spectrum Disorders, 5(2), 809-818.

[17] Gau, S. S.-F., Liu, L.-T., Wu, Y.-Y., Chiu, Y.-N., \& Tsai, W.-C. (2013). Psychometric properties of the Chinese version of the social responsiveness scale. Research in Autism Spectrum Disorders, 7(2), 349-360.

[18] Ghaziuddin, M. (2010). Brief Report: Should the DSM V Drop Asperger Syndrome? Journal of Autism Development Disorder, 40, 1146-1148. DOI 10.1007/s10803-010-0969-z.

[19] Happé, F. (1996). Autism. London, UK: UCL Press.

[20] Happé, F. \& Vital, P. (2009). What aspects of autism predispose to talent? Phil. Trans. R. Soc. B 364, 1369-1375. DOI: $10.1098 /$ rstb.2008.0332.

[21] Heavey, L.J. (1997). Memory in the calendar calculating savant. Unpublished $\mathrm{PhD}$ dissertation, Goldsmiths College, University of London.

[22] Heavey, L. (2003). Arithmetical savants. In A.J. Baroody \& A. Dowker (Eds.), The development of arithmetic concepts and skills: Constructing adaptive expertise. Studies in mathematical thinking and learning. (pp.409-433).Mahwah, NJ: Lawrence Erlbaum.

[23] Jackson, D. (2011, May 27). Time to challenge the rain man stereotypes- the autistic mind can be spectacularly creative. TES Newspaper, p. 25.

[24] Kuo C.C., Liang K.C., Tseng C.C., \& Gau, S.S.F. (2014). Comparison of the cognitive profiles and social adjustment between mathematically and scientifically talented students and students with Asperger's syndrome. Research in Autism Spectrum Disorders, August, 838-850. http://dx.doi.org/10.1 016/ j.rasd.2014.04.004.

[25] Lai M.-C., Lombardo M. V., Chakrabarti B, Baron-Cohen S. (2013). Subgrouping the Autism "Spectrum": Reflections on DSM-5. PLoS Biol, 11(4): e1001544. DOI: 10.1371/ journal.pbio.1001544.

[26] Liu, M. J.*, Shih, W. L., \& Ma, L. Y. (2011). Are children with Asperger syndrome creative in divergent thinking and feeling? A brief report. Research in Autism Spectrum Disorders,5(1), 294-298.

[27] Pring, L., Hermelin, B., \& Heavey, L. (1995). Savants, segments, art and autism. Journal of Child Psychology \& Psychiatry \& Allied Disciplines, 36(6), 1065-1076.

[28] Pring, L. Ryder, N., Crane, L, \& Hermelin, B. (2012). Creativity in savant artists with autism. Autism, 16(1), 4557. DOI: $10.1177 / 1362361311403783$

[29] Renzulli, J. S. (2002). Expanding the conception of giftedness to include co-cognitive traits and to promote social capital. Phi Delta Kappan, 84(1), 33-40, 57-58.

[30] Renzulli, J. S. (2003). Conception of giftedness and its relationship to the development of social capital. In $\mathrm{N}$. Colangelo \& G. A. Davis (Eds.), Handbook of gifted education, 3rd ed. pp.75-87. Boston: Allyn \& Bacon.

[31] Sacks, O. (1995). An anthropologist on Mars. Seven paradoxical tales. London, UK: Picador.

[32] Sloboda, J., Hermelin, B. \& O’Connor, N. (1985). An exceptional musical memory. Music Percept, 3, 155-170.

[33] Treffert, D. A. (2009). Islands of genius. Scientific American Special Edition, 14(1), 14-23.

[34] Tomlinson, C. (1999a). The differentiate classroom: Responding to the needs of all learners. Alexandria, VA: Association for Supervision and Curriculum Development.

[35] Tomlinson, C. (1999b). Mapping a route toward differentiated instruction. Educational Leadership, 57(1), 12-16.

[36] Van Tassel-Baska, J., Feng, A. X., Swanson, J. D., Quek, C., \& Chandler, K. (2009). Academic and affective profiles of low-income, minority, and twice-exceptional gifted learners: The role of gifted membership in enhancing self. Journal of Advanced Academic, 20(4), 702-739.

[37] Woodbury-Smith, M. R., \& Volkmar, F. R. (2009). Asperger Syndrome. European Child and Adolescent Psychiatry, 18, 2-11. DOI 10.1007/s00787-008-0701-0. 